\title{
Influence of food on morphological characteristics of Daphnia galeata (Cladocera, Daphnifiae) from Lake Baikal
}

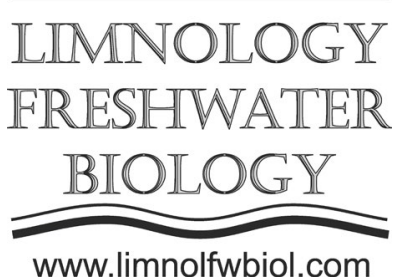

www.limnolfwbiol.com

\begin{abstract}
Pitul'ko S.I.
Limnological Institute of the Siberian Branch of the Russian Academy of Sciences, Ulan-Batorskaya 3, 664033 Irkutsk, Russia.

ABSTRACT. The study shows the influence of feeding conditions on morphological characteristics of Daphnia galeata (Sars, 1863) in different areas of Lake Baikal. At high food concentrations and in the absence of invertebrate predators of the species Leptodora kindti, the daphnids have a large body size, low helmets and short tail spines. At low food concentrations, crustaceans with small-sized shells, poorly developed helmets and tail spines dominate. In the presence of the predators, an abrupt shift of adaptive variation occurs: at low food concentrations, the crustaceans have a large body size, and at high ones, small adult daphnids with well developed protective patterns dominate.
\end{abstract}

Keywords: Lake Baikal, Daphnia galeata, food, morphological variability, the influence of predator

\section{Introduction}

The influence of food supply on the biology of cladocerans was widely studied as the most important environmental factor. The results of these studies showed that food quality and quantity influences body size, eggs size and amount, protective patterns development, life and development duration (Zhukova, 1953; Manuylova, 1964; Vijverberg, 1976; Gilyarov, 1987; Burns, 1995; Boersma and Vijverberg, 1996; Czeczuga et al., 2003; Freese and Martin-Creuzburg, 2013; Garbutt and Little, 2014). Food supply conditions strongly depend on temperature, illuminance, water currents velocity (Jacobs, 1987; Dodson, 1988; Manca et al., 2008; Gall et al., 2017). High water temperatures cause an increase in crustacean growth rate, requiring more food and, thus, this phenomenon occurs at high food concentrations (Zhukova, 1953; Vijverberg, 1976; Manca et al., 2008; Masclaux, 2009; Gorbi et al., 2011; Sarpe et al., 2014; Sicora et al., 2014). Body length is one of the most important features in the determination of daphnids weight and potential productivity. Moreover, it is one of the cyclomorphic traits. Hutchinson showed its role in adaptive reactions to environmental changes (Hutchinson, 1967). In our studies of influence of contrast feeding conditions, we showed that the majority of $D$. pulex clones manifests the same reaction at high food concentration (Pitul'ko et al., 2009). This is an increase in body size and of tail spine length, acceleration of development until maturation as well as a rise of reproduction and abundance of survived crustaceans.

The impact of invertebrate predators on the variability of morphological features of daphnids is well known; as a rule, it concerns premature and small adult crustaceans, and there is no direct impact on juvenile and mature crustaceans of elder age groups (Lagergren et al., 2007; Manca et al., 2008; Zuykova and Bochkarev, 2010). Under favorable feeding conditions, the predators do not impact the daphnids body size, but helmets and tail spines are well developed (Brooks, 1946; Dodson, 1988; 1989; Laforsh and Tollrian, 2004; Hülsmann et al., 2011).

The influence of concentration of available food and invertebrate predators on morphological characteristics of daphnids has not been studied for Lake Baikal. Daphnia galeata (Sars, 1863) is a widely distributed species of the genus Daphnia in the lake (Sheveleva, 1996; 2001). These cladocerans inhabit bays, sors and near-shore shallow waters. They play a considerable role in the formation of food resources for the organisms of the next level of the food chain during several summer and autumn months. Phytoplankton, detritus, bacteria, and protozoa are the main food of planktonic crustaceans. They consume cells within the size range of 3-30 $\mu \mathrm{m}$ (Monakov, 1998). The daphnids prefer small protococci with a diameter of $3.5 \mu \mathrm{m}$, then, Scenedesmus $(15 \mu \mathrm{m})$ and Chlorococcum $(20-30 \mu \mathrm{m})$, as well as species of the genus Chroomonas: Ch. acuta $\mu \mathrm{m}$ and Ch. sp. (7-11 $\mu \mathrm{m}$ long and 3-7 $\mu \mathrm{m}$ wide) and Stephanodiscus binderanus (diameter of 7.5-12.3 $\mu \mathrm{m}$ ) found in Lake Baikal phytoplankton (Bondarenko et al., 1991; 1995). Algae of the genus Chroomonas dominate phytoplankton. In Baikal, maximum phytoplankton abundance is in Chivyrkuy and Barguzin Bays, the minimum abundance is in Southern and Northern Baikal (Antipova, 1963; Bondarenko et al., 1991;1995).

*Corresponding author.

E-mail address: pitulko@inbox.ru (S.I. Pitul'ko) 
The aim of this study is to assess the influence of accessible food concentration on some morphological traits of Daphnia galeata and to analyze adaptive responses of these crustaceans by the studied features in the presence or absence of the predator Leptodora kindtii.

\section{Materials and methods}

Crustaceans $D$. galeata and $L$. kindti were collected with Juday net (inlet area is $0.1 \mathrm{~m}^{2}$, filter cone mesh is $90 \mu \mathrm{m}$ ) in the Lake Baikal pelagic area and bays in August-September, 1993, 1995 and 1997 at 36 stations. The samples were fixed with $4 \%$ formalin. Main materials were obtained in two large bays (Barguzin and Chivyrkuy Bays - St. 18-33), as well as in the pelagic area of Central Baikal (St. 10-17). In addition, we used the data on the near-shore shallowwater area near the Ushkany Islands (St. 27), Selenga area (St. 8-9), the near-shore area of Southern Baikal (St. 1-9), and Northern Baikal (St. 34-36) (Fig. 1). At stations located mainly in Central Baikal and bays (6, 10, 18, 23-26, 28-31), L. kindti was recorded. At low food concentration, there were 5 such stations out of 16 ones, and at high food concentration - 10 stations out of 12 ones.

The obtained and selected daphnids were classified as mature, premature and juvenile females. In total, 2525 specimens were studied. The morphological variation in $D$. galeata was measured by the following characteristics: body length, height of the helmet and tail spine length (Fig. 2), as well as the calculated relationship between these traits, the relative height of the helmet and the relative length of the tail spine (Manuylova, 1964; Havel, 1985; Ranta and Tjossem, 1987; Dodson, 1988; 1989; Ranta et al., 1993; Riccardi et al., 2002). We determined body length, helmet height and tail spine length (Fig. 2) as well as calculated the ratio of helmet height and tail spine length to body length. Relative characteristics showed allometric growth of body parts under certain existence conditions and assessed the development of cyclomorphic features (Havel and Dodson, 1985).

To characterize the food supply level of daphnids, we used the daily production of phytoplankton in $\mathrm{mg}$ of carbon per $\mathrm{m}^{3}\left(\mathrm{mg} \mathrm{C} / \mathrm{m}^{3}\right)$. This is an integrated indicator showing total food concentrations in daphnids habitats. Previous reports imply distribution of bacterioplankton and phytoplankton abundance in the food of inferior crustaceans in the Lake Baikal water area. Based on the data shown in Bondarenko et al. (1991), we established seven grades of food concentration. Its minimum (19 $\mathrm{mg} \mathrm{C} / \mathrm{m}^{3}$ ) was recorded in Southern Baikal (Stations 1-7). In the range areas of Chivyrkuy and Barguzin Bays, food concentrations were 30.0 and $35.0 \mathrm{mg}$ $\mathrm{C} / \mathrm{m}^{3}$, respectively (St. $19,25,26,30$, and 33 ). In Central and Northern Baikal, values of phytoplankton daily production were $38 \mathrm{mg} \mathrm{C} / \mathrm{m}^{3}$ (St. 11-17, 27 and 34-36). In the Selenga shallow-water area, this value is $160 \mathrm{mg} \mathrm{C} / \mathrm{m}^{3}$ (St. 8-10). Within Barguzin and Chivyrkuy Bays, food concentrations were $190 \mathrm{mg} \mathrm{C} /$

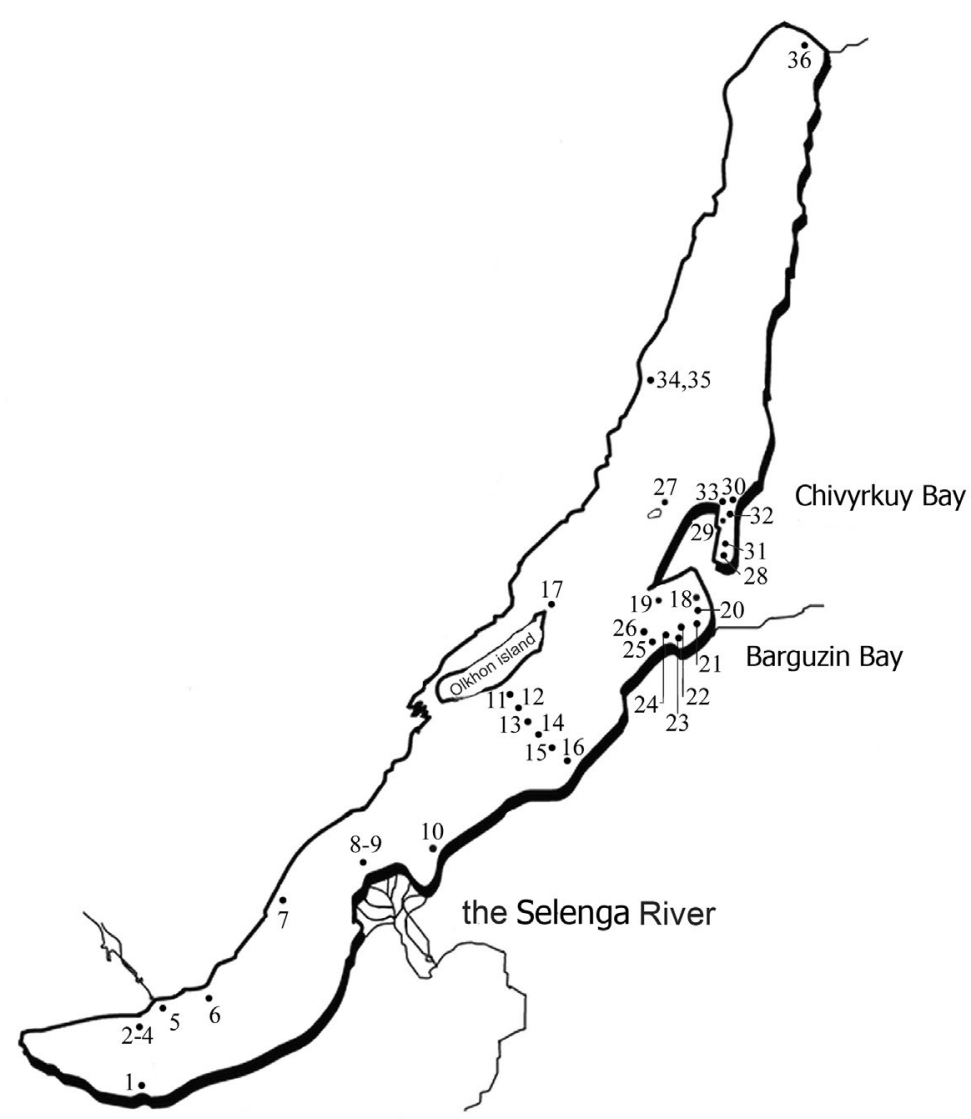

Fig.1. Stations of zooplankton sampling in Lake Baikal in 1993-1997. Numbers are stations

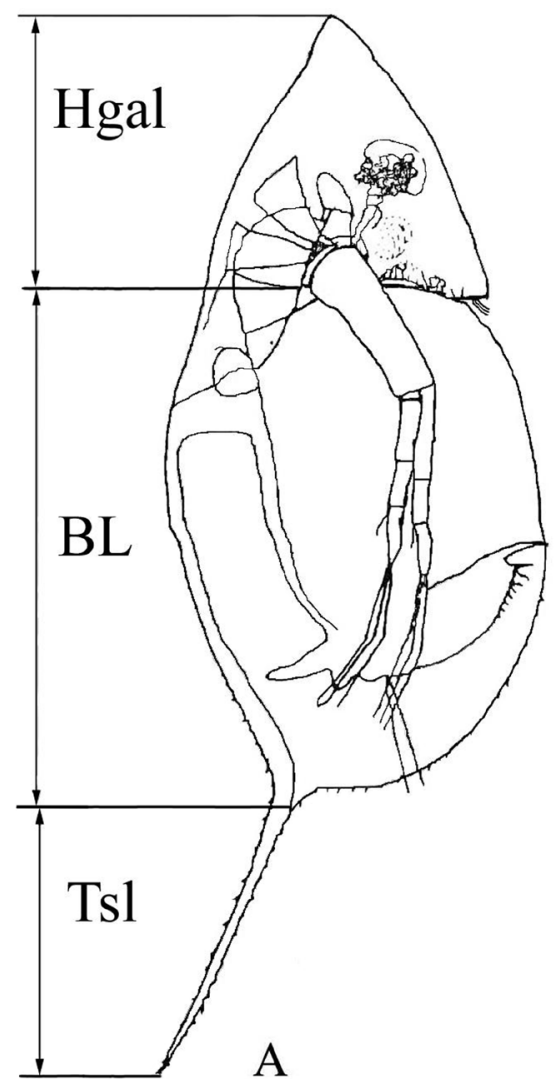

Fig.2. Scheme of morphological traits measurements: $\mathrm{HH}$ - helmet height, BL - body length, Tsl - tail spine length 
$\mathrm{m}^{3}$ (St. 18, 20 and 22-24) and $250 \mathrm{mg} \mathrm{C} / \mathrm{m}^{3}$ (St. 28-29 and 21-32), respectively. According to the above data, the established grades are two qualitatively different groups. In the first four ones, the concentrations were by one order of magnitude lower than in the other three ones. Due to this fact, we indicated food concentrations of $19-38 \mathrm{mg} \mathrm{C} / \mathrm{m}^{3}$ as low, and those of $160-250 \mathrm{mg} \mathrm{C} /$ $\mathrm{m}^{3}$ as high.

In order to distinguish the influence of predator and a certain concentration of accessible food on the variability of morphological features, we used the following approach. Firstly, we analyzed the morphological variability of daphnids at low and high food concentrations for the whole data set. Then, based on the same concentrations, we used two selected groups in the presence and absence of the invertebrate predator $L$. kindti in the samples.

The results were statistically processed using standard methods. According to the obtained data, the average value of the trait and the error of the average were calculated. Differences were estimated using Student's test. (Rokitskii, 1973).

\section{Results}

Table 1 shows variations of the studied features under different conditions (food concentration and presence or absence of predators). Notably, the studied age stages differ significantly by body size. The analysis of results for the whole data set has indicated that body length in juvenile, premature $(\mathrm{t}=4.77, \mathrm{t}=6.99, \mathrm{P}$ $<0.001)$ and adult crustaceans $(\mathrm{t}=2.32, \mathrm{P}<0.05)$ is indeed larger at high levels of food supply than at low ones. However, mature and premature crustaceans without and with predators clearly demonstrate a different response to feeding conditions. In predatorfree sets, their body length is considerably larger at high concentrations, whereas in the sets with predators, mature daphnids are indeed larger at low food level $(\mathrm{t}=4.48, \mathrm{P}<0.001)$ than at high one, and premature daphnids do not differ statistically $(\mathrm{t}=$ 0.55). With predators, the body length at all daphnids age groups is larger under different feeding conditions, except for adult specimens at high food supply. Large sizes of crustaceans allow them to have large reserves of nutrients and avoid selective predation due to the size, since invertebrate predators consume mainly small crustaceans. In various elder age groups, juvenile crustaceans do not differ in body size regardless of food concentrations, as well as the presence or absence of predator.

According to all available data, the helmet height in juvenile, premature and mature crustaceans is obviously larger at high concentrations of accessible food. In predator-free set, all studied age stages have no valuable differences in the helmet height, both at low and at high food concentrations. In the presence of predators, juvenile, premature and mature crustaceans have considerably higher helmets at high food concentrations $(P<0.001)$. On the whole, in the presence of predator, both at low and at high food concentration, the helmet is higher than at the same food concentration but without predator. Typically, in predator-free sets, specimens of all age groups have low helmets, without any difference in daphnids sampled at different food concentrations, while in the sets with predators, all specimens of any age stage have high helmets at any food concentrations. This suggests that the presence of predators rather than by food concentration influences the helmet height. In samples with predators at all food concentrations, the helmet is higher than in the absence of predator $(\mathrm{P}<0.001)$. In general, the reaction of organisms estimated by the height of the helmet to the studied conditions is obvious.

According to all available data, tail spines at high food concentrations are significantly longer at high concentrations of food than at low ones. At the same time, in predator-free sets, mature and premature crustaceans have no obvious differences in this feature both at high and low food levels. However, the tail spine length in juvenile crustaceans is considerably larger at high food concentrations $(\mathrm{t}=5.83, \mathrm{P}<$ $0.001)$. In sets with predators, mature and premature crustaceans have obviously longer tail spines at high food concentrations $(\mathrm{t}=5.09, \mathrm{P}<0.001$ in mature specimens and $\mathrm{t}=4.33, \mathrm{P}<0.001$ in premature specimens). In juvenile crustaceans, the tail spine length does not differ significantly, both at low and at high food concentration. Under all trophic conditions, in the presence of predators, specimens of all age stages have considerably longer tail spines.

Relative helmet height in all analyses indicates the highest values in premature and juvenile crustaceans and the lowest ones in mature daphnids. According to all obtained data, relative helmet size in daphnids of all age stages is large at high food concentrations ( $P$ $<0.001)$. However, in predator-free sets, this value is obviously lower in mature and juvenile crustaceans at high food concentrations $(\mathrm{t}=2.42, \mathrm{P}<0.05 ; \mathrm{t}=$ $2.51, \mathrm{P}<0.05$, respectively), and does not differ in premature ones. In the presence of predators, all age groups have a considerably greater relative helmet height at high food concentrations $(\mathrm{P}<0.001)$; moreover, this value is considerably higher at all food concentrations than under predator-free condition. It should be noted that in the presence of predators, at high food concentrations, values of this feature in mature crustaceans increase significantly compared to predator-free conditions.

Relative tail spine length has high values in juvenile and mature specimens and low ones - in mature crustaceans. The analysis of the results for the whole data set on mature $(\mathrm{t}=5.53, \mathrm{P}<0.001)$, premature $(\mathrm{t}=2.21, \mathrm{P}<0.5)$ and juvenile $(\mathrm{t}=4.15$, $\mathrm{P}<0.001)$ stages showed that relative tail spine length is considerably greater at high food concentrations. Under predator-free conditions, at high food concentrations, this value is obviously lower in adult and premature daphnids $(\mathrm{t}=3.86, \mathrm{P}<0.001$ and $\mathrm{t}=$ $4.18, \mathrm{P}<0.001$, respectively). In juvenile crustaceans, the relative tail spine length is considerably higher at high food concentrations $(\mathrm{t}=2.40, \mathrm{P}<0.001)$ than 
Table 1. Morphological features of Daphnia galeata of different age groups at low and high levels of food supply

\begin{tabular}{|c|c|c|c|c|c|c|c|}
\hline \multirow{3}{*}{ Characters } & \multicolumn{7}{|c|}{ Analysis options } \\
\hline & \multirow[b]{2}{*}{ Age } & \multicolumn{2}{|c|}{ All data } & \multicolumn{2}{|c|}{ Without predators } & \multicolumn{2}{|c|}{ With predators } \\
\hline & & $\begin{array}{c}\text { Low food } \\
\text { concentration }\end{array}$ & $\begin{array}{c}\text { High food } \\
\text { concentration }\end{array}$ & $\begin{array}{c}\begin{array}{c}\text { Low food } \\
\text { concentration }\end{array} \\
\end{array}$ & $\begin{array}{c}\text { High food } \\
\text { concentration }\end{array}$ & $\begin{array}{c}\text { Low food } \\
\text { concentration }\end{array}$ & $\begin{array}{c}\text { High food } \\
\text { concenration }\end{array}$ \\
\hline \multirow{3}{*}{$\begin{array}{c}\text { Number } \\
\text { of studed } \\
\text { individuals }\end{array}$} & Mature & 818 & 405 & 595 & 78 & 223 & 327 \\
\hline & Premature & 274 & 108 & 174 & 20 & 100 & 88 \\
\hline & Juvenile & 590 & 330 & 432 & 90 & 158 & 240 \\
\hline \multirow{3}{*}{$\begin{array}{l}\text { Body length } \\
\quad(\mu \mathrm{m})\end{array}$} & Mature & $948.2 \pm 4.14$ & $965.1 \pm 6.01 *$ & $927.2 \pm 4.82$ & $976.4 \pm 15.91^{* * *}$ & $1004.3 \pm 6.81$ & $962.4 \pm 6.40^{* * *}$ \\
\hline & Premature & $790.0 \pm 4.04$ & $840.7 \pm 6.03^{* * *}$ & $757.0 \pm 4.20$ & $829.1 \pm 10.16^{* * *}$ & $847.5 \pm 4.12$ & $843.2 \pm 6.91$ \\
\hline & Juvenile & $615.4 \pm 4.63$ & $654.0 \pm 6.65^{* * *}$ & $590.6 \pm 4.84$ & $609.7 \pm 11.62$ & $682.9 \pm 9.18$ & $670.6 \pm 7.78$ \\
\hline \multirow{3}{*}{$\begin{array}{c}\text { Helmet } \\
\text { height }(\mu \mathrm{m})\end{array}$} & Mature & $121.9 \pm 0.98$ & $160.1 \pm 2.91^{* * *}$ & $118.4 \pm 0.94$ & $112.9 \pm 3.67$ & $131.3 \pm 2.46$ & $171.3 \pm 3.20^{* * * *}$ \\
\hline & Premature & $114.8 \pm 1.80$ & $174.2 \pm 6.25^{* * *}$ & $105.3 \pm 1.76$ & $111.3 \pm 4.04$ & $131.3 \pm 3.29$ & $189.0 \pm 7.10^{* * * *}$ \\
\hline & Juvenile & $98.8 \pm 1.26$ & $129.2 \pm 2.89^{* * *}$ & $90.9 \pm 1.19$ & $87.9 \pm 2.32$ & $120.4 \pm 2.77$ & $144.7 \pm 3.37^{\text {***** }}$ \\
\hline \multirow{3}{*}{$\begin{array}{l}\text { Tail spine } \\
\text { length }(\mu \mathrm{m})\end{array}$} & Mature & $459.9 \pm 2.67$ & $496.3 \pm 4.29 * *$ & $454.2 \pm 3.10$ & $441.3 \pm 9.46$ & $474.7 \pm 5.10$ & $509.4 \pm 4.52^{* * * *}$ \\
\hline & Premature & $422.4 \pm 3.14$ & $469.1 \pm 7.80^{* * *}$ & $411.8 \pm 3.29$ & $407.8 \pm 8.34$ & $440.9 \pm 6.01$ & $482.6 \pm 8.73^{\cdots * *}$ \\
\hline & Juvenile & $348.9 \pm 3.46$ & $397.7 \pm 3.86 * * *$ & $330.5 \pm 3.96$ & $369.3 \pm 5.36^{* * * *}$ & $399.2 \pm 5.34$ & $408.3 \pm 4.73$ \\
\hline \multirow{3}{*}{$\begin{array}{c}\text { Relative } \\
\text { helmet } \\
\text { height }\end{array}$} & Mature & $0.130 \pm 0.0028$ & $0.169 \pm 0.0033 * * *$ & $0.129 \pm 0.0010$ & $0.118 \pm 0.0044 *$ & $0.132 \pm 0.0025$ & $0.181 \pm 0.0036^{* * * *}$ \\
\hline & Premature & $0.145 \pm 0.0021$ & $0.206 \pm 0.0074 * * *$ & $0.140 \pm 0.0023$ & $0.135 \pm 0.0050$ & $0.155 \pm 0.0039$ & $0.223 \pm 0.0079 * * *$ \\
\hline & Juvenile & $0.162 \pm 0.0018$ & $0.198 \pm 0.0039 * * *$ & $0,156 \pm 0,0020$ & $0.146 \pm 0.0036^{*}$ & $0.177 \pm 0.0035$ & $0.217 \pm 0.0046^{* * * *}$ \\
\hline \multirow{3}{*}{$\begin{array}{l}\text { Tail spine } \\
\text { relative } \\
\text { length }\end{array}$} & Mature & $0.489 \pm 0.0028$ & $0.519 \pm 0.0048 * * *$ & $0.493 \pm 0.0032$ & $0.458 \pm 0.0101 * * *$ & $0.476 \pm 0.0056$ & $0.534 \pm 0.0051 * * *$ \\
\hline & Premature & $0.537 \pm 0.0041$ & $0.558 \pm 0.0086^{*}$ & $0.546 \pm 0.0049$ & $0.493 \pm 0.0116^{* * *}$ & $0.521 \pm 0.0070$ & $0.573 \pm 0.0096 * * *$ \\
\hline & Juvenile & $0.587 \pm 0.0506$ & $0.615 \pm 0.0046 * * *$ & $0.584 \pm 0.0061$ & $0.614 \pm 0.0093^{*}$ & $0.583 \pm 0.0089$ & $0.615 \pm 0.0054 * *$ \\
\hline
\end{tabular}

Note: * $-\mathrm{P}<0.05 ; * *-\mathrm{P}<0.01 ; * * *-\mathrm{P}<0.001$

at lower ones. In the presence of predators, specimens of all age stages have considerably longer tail spines at high concentrations $(t=5.09, P<0.001)$ than at lower ones. We indicate that in the presence of predators at high food concentrations, this ratio has maximum values in all age groups.

\section{Discussion}

The obtained results show that both food concentration and predators affect morphological variability of $D$. galeata in Lake Baikal. Moreover, daphniids are likely to be affected by temperature, since high food concentrations were recorded in the bays with higher water temperature (Bondarenko et al., 1991).

The body size of adult and premature daphniids is larger in the absence of predators and at high food concentrations than at low food concentrations. Under such conditions, Daphnia grow faster at all stages and their growth continues after reaching maturity (Vijverberg, 1976; Gilyarov, 1987; Romanovsky, 1989;
Burns, 1995; Czeczuga et al., 2003; Rinke and Vijverberg, 2005; Freese and Martin-Creuzburg, 2013; Sarpe et al., 2014; Sicora et al., 2014; Gall et al., 2017). Juvenile daphniids have the smallest body size in the absence of predators and at high concentrations of food, since they have minimum sizes with birth and a limited supply of nutrients (Zhukova, 1953; Jacobs, 1987; Dodson, 1989; Gorbi et al., 2011). Mature Daphnia have smaller body size in the presence of predators and at high food concentrations. This may be due to the selection in food for numerous predators (Dodson, 1988; 1989; Riccardi et al., 2002; Lagergren et al., 2007; Manca et al., 2008; Korzun and Pitul'ko, 2010; Hülsmann et al., 2011).

The largest crustaceans are recorded in the presence of predators and at low food concentrations. Their large body size prevents from capture by predators and ensures their efficient filtering of food (Havel, 1985; Havel and Dodson, 1985; Dodson, 1988). We have determined that the body size of juvenile and premature crustaceans do not differ in the presence of predators at low and high food concentrations. However, their body size is larger at all food concentrations compared to 
Daphnia without predators. Thus, predators positively influence on the growth rate of immature crustaceans. A helmet, tail spine and their relative sizes are less developed in the absence of predators and vice versa. Previously it was shown that the portion of Daphnia morphotypes with a high helmet and long tail spine (spined morphotype) is increased under high densities of predators (Korzun and Pitul'ko, 2010; Tams et al., 2018). Consequently, the studied structures have a protective function against predators.

\section{Conclusion}

Thus, the body size increases but the helmet size and tail spine length decrease at high concentrations of available food. The presence of a predator favours strong development of protective structures in mature and premature Daphnia. Juvenile crustaceans in the absence of predators have the smallest dimensions, whereas in their presence they are larger regardless of the food concentration. Therefore, $D$. galeata possess different adaptive responses to changes in food conditions in the presence or absence of predators. Without predators and at low food concentrations, crustaceans grow slower until maturity; then, the growth stops. These crustaceans have a smaller body size but a higher helmet and longer tail spine. In the bays with rich food, the body grows fast throughout life. Different adaptive responses are observed in crustaceans in the presence of predator depending on the conditions of the food supply. Large mature daphnids survive in a lack of food and under pressure of predators; however, they possess weak protective structures. At high food concentrations and strong pressure of predators, mature crustaceans have a smaller body size with more developed protective structures than those at low food concentrations. Therefore, food conditions play a crucial role in adaptive strategies. Different adaptive responses caused by changes in various environmental parameters favour sustainable conservation of Daphnia populations and the prevention of their death.

\section{Acknowledgements}

We thank V.M. Korzun for the help, advice and friendly criticism in the course of the work on the manuscript and Julia Kaplyukova for translation of the manuscript from Russian into English. The work was performed within the project No. 51.1.1.10 "State, biodiversity and ecology of the coastal zone of Lake Baikal." O.A. Timoshkin).

\section{References}

Antipova N.L. 1963. Seasonal and annual variations in Lake Baikal phytoplankton. In: Trudy Baikalskoi limnologicheskoi stantsii AN SSSR [Proceedings of the Baikal Limnological Station of the Academy of Sciences of the USSR], pp. 12-18. (in Russian)

Bondarenko N.A., Grachev M.A., Zemskaya T.I., Logacheva N.F., Levina O.V. 1991. ATP content in microplankton of certain regions of Lake Baikal. Soviet Journal of Ecology 22:
380-387.

Bondarenko N.A., Obolkina L.A., Mel'nik N.G., Zemskaya T.I., Logacheva N.F. 1995. Interspecific links and structure of planktonic communities. 1.2. Phytoplankton. In: Timoshkin O.A. (Ed.), Guide and key to pelagical animals of Baikal (with ecological notes). Novosibirsk, pp. 60-61. (in Russian)

Boersma M., Vijverberg J. 1996. Food effects on life history traits and seasonal dynamics of Ceriodaphnia pulchella. Freshwater Biology 35: 25-34.

Brooks J.L. 1946. Cyclomorphosis in Daphnia I. An Analysis of a $D$. retrocurva and $D$. galeata. Ecological Monographs 16: 409-447.

Burns C.W. 1995. Effect of crowding and different food levels on growth and reproductive investment of Daphnia. Oecologia [Ecology] 101: 234-244.

Czeczuga B., Kozłowska M., Kiziewicz B. 2003 Effect of various types of phytoplankton on fertility, egg size and duration of postembryonic growth of a few plankton representatives of Cladocera (Crustacea). Polish Journal of Environmental Studies 12: 545-555.

Dodson S.I. 1988 Cyclomorphosis in Daphnia galeata mendotae Birge and $D$. retrocurva Forbes as a predator-induced response. Freshwater Biology 19: 109-114. DOI: 10.1111/ j.1365-2427.1988.tb00332.x

Dodson S.I. 1989. The ecological role of chemical stimuli for the zooplankton: predator-induced morphology in Daphnia. Oecologia [Ecology] 78: 361-367.

Freese H.M., Martin-Creuzburg D. 2013. Food quality of mixed bacteria-algae diets for Daphnia magna. Hydrobiologia 1: 63-76.

Garbutt J.S., Little T.J. 2014. Maternal food quantity affects offspring feeding rate in Daphnia magna. Biology Letters 10: 1-15. DOI: 10.1098/rsbl.2014.0356

Gall A., Kainz M.J., Rasconi S. 2017. Daphnia magna fitness during low food supply under different water temperature and brownification scenarios. Journal of Limnology 76: 161-169. DOI: $10.4081 /$ jlimnol.2016.1450

Gilyarov A.M. 1987. Dynamics of the abundance of freshwater planktonic crustaceans. Moscow: Nauka. (in Russian)

Gorbi G., Moroni F., Sei S., Rossi V. 2011. Anticipatory maternal effects in two different clones of Daphnia magna in response to food shortage. Journal of Limnology 70: 222-230. DOI: $10.3274 / \mathrm{JL} 11-70-2-05$

Jacobs J. 1987. Cyclomorphosis in Daphnia. Memorie dell'Istituto Italiano di Idrobiologia [Memories of the Italian Institute of Hydrobiology] 45: 325-352.

Jeyasingh P.D., Weider L.J. 2005. Phosphorus availability mediated plasticity in life-history traits and predator-prey interaction in Daphnia. Ecology Letters 10: 1021-1028. DOI: 10.1111/j.1461-0248.2005.00803.x

Havel J.E. 1985. Cyclomorphosis of Daphnia pulex spined morphs. Limnology and Oceanography 30: 853-861.

Havel J.E., Dodson S.I. 1985. Environmental cues for cyclomorphosis in Daphnia retrocurva. Freshwater Biology 15: 469-478.

Hülsmann S., Rinke K., Mooij W.M. 2011. Sizeselective predation and predator-induced life-history shifts alter the outcome of competition between planktonic grazers. Functional Ecology 25: 199-208. DOI: 10.1111/j.1365-2435.2010.01768.x

Hutchinson G.E. 1967. A treatise on limnology. Volume II. Introduction to lake biology and the limnoplankton. New York-London-Sydney: John Wiley and Sons.

Korzun V.M., Pitul'ko S.I. 2010. Phenotypic variation and adaptive reaction to the presence of predator in two Daphnia species (Daphniiformes, Daphnia) in Lake Baikal. Russian Journal of Ecology 41: 316-321. DOI: 10.1134/ S1067413610040065 
Laforsh Ch., Tollrian R. 2004. Extreme helmet formation in Daphnia cucullata induced by small-scale turbulence. Journal of Plankton Research 26: 81-87. DOI: 10.1093/ plankt/fbg114

Lagergren R., Svensson J.-E., Stenson J.A.E. 2007. Models of ontogenetic allometry in cladoceran morphology studies. Hydrobiologia 594: 109-116.

Manca M., Vijverberg J., Polishuk V., Voronov D.A. 2008. Daphnia body size and population dynamics under predation by invertebrate and fish predation in Lago Madjiore approach based on contribution analysis. Journal of Limnology 67: 15-21.

Manuylova E.F. 1964. Cladocera of the fauna in the USSR. Keys to the USSR fauna, published by the Zoological Institute of the USSR Academy of Sciences 88. Moscow-Leningrad: Nauka Publishers. (in Russian)

Monakov A.I. 1998. Feeding of freshwater invertebrates. Moscow: Institute of Ecology and Evolution RAS. (in Russian)

Masclaux H., Bec A., Kainz M.J., Desvilettes C., Jouve L., Bourdier G. 2009. Combined effects of food quality and temperature on somatic growth and reproduction of two freshwater cladocerans. Limnology and Oceanography 4: 1323-1332. DOI: 10.4319/1o.2009.54.4.1323

Pitul'ko S.I., Yermakov Ye.L., Korzun V.M. 2009. Variability of Daphnia clonal cultures by a set of quantitative features under contrast feeding conditions. Izvestiya Irkutskogo Gosudarstvennogo Universiteta. Seriya "Biologiya, Ecologiya" [The Bulletin of Irkutsk State University. Series "Biology, Ecology"] 2: 83-86. (in Russian)

Pitul'ko S.I., Korzun V.M. 2010. Study of cyclomorphosis in two baikalian daphniid species. Baykal'skiy Zoologicheskiy Zhurnal [Baikal Zoological Journal] 5: 10-19. (in Russian)

Ranta E., Tjossem S. 1987. Size and shape of Daphnia longispina in rock pool. Hydrobiologia 145: 259-268.

Ranta E., Bengtsson J., McManus J. 1993. Growth, size and shape of Daphnia longispina, D. magna and D. pulex. Annales Zoologici Fennici 30: 299-311.

Riccardi N., Giussani G., Lagorio L. 2002. Morphological variation and life history changes of a Daphnia hyalina population exposed to Chaoborus flavicans larvae predation (L. Candia, Northern Italy). Journal of Limnology 61: 41-48. DOI: $10.4081 /$ jlimnol.2002.41

Rinke K., Petzoldt Th. 2003. Modeling the effects of temperature and food on individual growth and reproduction of Daphnia and their consequences on the population level. Limnologica 4: 229-376. DOI: 10.1016/ S0075-9511(03)80024-5

Rokitskii P.F. 1973. Biological statistics. Minsk: Vysshaya Shkola. (in Russian)

Romanovsky Yu. E. 1989. Competition for fluctuating resource: an evolutionary ecological study. Zhurnal obshchei biologii [Biology Bulletin Reviews] 3: 304-314. (in Russian)

Sarpe D., de Senerpont Domis L.N., Declerck S.A.J., Donk E., Ibelings B.W. 2014. Food quality dominates the impact of food quantity on Daphnia life history: possible implications for re-oligotrophication. Inland Waters 4: 363-368. DOI: 10.5268/IW-4.4.701

Sheveleva N.G. 1996. The species composition and distribution of cladocerans in Lake Baikal. Zoologicheskiy Zhurnal [Biology Bulletin] 75: 312-315. (in Russian)

Sheveleva N.G. 2001. Cladocera (Ctenopoda, Anamopoda, Haplopoda, Onychopoda). In: Annotated list of fauna of Lake Baikal and of its water catchment basin. Vol. 1: Lake Baikal. Novosibirsk, pp. 491-496. (in Russian)

Schultz K.L., Sterner R.W. 1999. Phytoplankton phosphorus limitation and food quality for Bosmina. Limnology and Oceanography 6: 1549-1556. DOI: 10.4319/ 10.1999.44.6.1549

Sicora A.B., Dawidowicz P., von Elert E. 2014. Daphnia fed algal food grown at elevated temperature have reduced fitness. Journal of Limnology 3: 421-427. DOI: 10.4081/ jlimnol.2014.898

Tams V., Lüneburg J., Seddar L., Detampel Jan-Phillip., Cordellier M., 2018. Intraspecific phenotypic variation in life history traits of Daphnia galeata populations in response to fish kairomones. PeerJ 6. DOI: 10.7717/peerj.5746

Vijverberg J. 1976. The effect of food quantity and quality on the growth, birth rate and longevity of Daphnia hyalina Leydig. Hydrobiologia 51: 99-108.

Zhukova N.A. 1953. Cyclomorphosis in daphnia. Trudy Leningradskogo pedagogicheskogo instituta [Proceedings of the Leningrad Pedagogical Institute] 7: 85-148. (in Russian)

Zuykova E.I., Bochkarev N.A. 2010. Postembryonal morphological variation of Daphnia galeata in water bodies of different types. Contemporary Problems of Ecology 3: 28-40. DOI: 10.1134/S1995425510010066 